\title{
Homenagem do Centenário da Opas à Abem
}

\section{Paho Centennial Tribute to Abem}

Dr. José Paranaguá Sant Ana*

Como parte das comemorạ̧ocs de seu centenário no Brasil, a Organização Pan-Americarı da Saúde (Opas) prestou uma homenagem especial à Associaça Brasileira de Educação Médica (Abem), durante seu XL Congresso, ressaltando a importância do trabalko desenvolvido por esta instituiçăo e. sobrctudo. a singularidade da parceria que com ela foi possivel desenvolver dumnte quatro decadas.

Essa relaça começou, com apoio das Fundaçoses Millbank e Kellogg, no prucesso de criaçào da Federąăa Pan-Americana de Associaçoes de Faculdades de Medicina (Fepafem). As negociaçoes para a criaçăo da Abem tiveram início durante a III Conferència Latino-Arnericana de Escolas Médicas. realizada tno Chile em 1960, e chegaram a bom termo em agosto de 1962, quando se reuniram em Belo Horizonte os representantes de 26 das 34 escolas intåo existentes. Na ocasiăo. lavrou-se a ata de fundação da Associaçáo Brasileira de: Escolas Medicas, tendo sido cleito presidente o diretor da Faculdade de Medicim da L:MG. Osear Versiani C.aldeira. que havia convocado a reunião. Desse ato participou Ramon Villareal. entån diretor do Departamento de Lesenvolvimento de Recursus Humanos da Opas. A partir de entalo, a Organizaça abrigess em sua própria sede: na Rua l’aissaludu, sus Kio de jaskiro, a primeira Dirctoria Executiva da Abem. a cargo de José Roberto Ferreira.

Logo no inicio de sua existência, a Abem publicou o primeiro relatório técnico sobre a Educaçă Médica sk) Brasil, no inomento em que se iniciava o processo de expansāo acelerada do núnuro de escolas. Desemrolveu-se a partir dá uma orientaçăo que. além da preocupaço com o currículo minimo estabelecido pelo Conselho Federal de Éducaça, buscava considerar aspectos relativos d oferta c demanda de vagas, ao aprimoramento pedagógico e à modernizaçåo de instalaçoes e equipamentos.

Em 1974, foram modificaslos os Estatutos da Aixem, que deixou de ser apenas de Escolas Médicas para abranger toda a Educação Médica, ampliando suas possibilidades de participaçăo neste campo educacional. Expressão disso e a publicaçăo de sua Revisla Brasileria de Éctucacaco Mledica, que desde 1977 maniém ediçôes quadrimestrais. sendo um dos poucos periódicos do género na América Latina.

A Abem participou do prosesso de escolha da sede da Biblioteca Regional de Medicina (Bireme). que a Opas implantou na Éscola Paulista de Mcdicina, atual Universidade Fedcral de Såo Paulo (Unifesp). e, nos anos subsequentes. acompanhou o impacto dessa iniciativa - ampliação significativa do acesso à informaçà̆o bibliográfica, com o avanço até os dias atuais répresentado pela Biblioteca Virtual em Saúde.

Igualmente, a Associaçăo foi participe do desenvolvimento do Programa de Livros de Texto da Orga. rizaçăo (Paltex), mediante designação de seus membros pars os comitès de selcçăo de livros c, inclusive, a incorporaçào de livros de autores brasileiros. mais ajustados à realidade do País.

A parceria com a Opas ocorreu também no apoio d̀ realizaçăo de suas reunises anuais, bem como de un nimero signíficativo de seminários e grupos $\alpha$ traball $x$ ) sobre ternas sclecionados. incluindo. $\mathrm{cm}$ mustos casos, a publicaçăo conjunta dos respectivos documentos técnicos ou relatórios finais. Quando seu primeiro diretor executiso foi convidado a integrar o quadro da Otģanização. kendo assumido em 197.4 a Direç̧ăo do Departamento de Desenvolvimento de Recursos Humanos. em W'ashinyton. esta colaboraçăo fe\%-se ainda mais ampla. Niessa época. foi criado, na Representação da Opas no Brasil. o 
Programa de Preparaçåo de Pessoal Estrallegico para a Saúde (Preps), sob a coordenaç̧o de Carlyle Cuerra de Macedo, e, nesse âmbito. fortaleceu-se a cooperação com a Associaç̧ao e com suns escolas filiadas.

Durante a década de 90 . a $\mathrm{Abcm}$ liderou um importante esforço de articulaçăo entre diversas entidades nacionais, dentre as quais a Associação Médica Brasilera c o Conselho Federal de Medicina, com o objetivo de avaliar em toda a sua amplitude o Ensino Médico no Pais: a Comissão Interinstitucional Nacional de Avaliaçióo da Educa. ção Médica (Cinacm). Essa Comissåo promoveu a avaliaçăo do processo formativo e a caractcrizaç̧o das instituiçoes e recursos envolvidos, discutindo o ensino $:$ a profissāo médica com representantes docentes e discentes das proprias escolas c com diversos segmentos da sociedade civil. No início de seus trabalhos. a Cinaem tomou como referência documentos e p:opostas de avaliaçăo da Educaçîno Mlédica publicados pela Opas.
Vale ainda destacar que a $\mathrm{Abem}$ vem participando ativamente em programas ceesenvolvidos pelo Ministério da Saúde com apoio da Opas, que incluem componentes que visam ajustar a formaçå médica ds necessidades dos serviços públicos de saúde: o Programa de Saúde da Famillia (|SłH) o I'rograma de Interiorização do Trabalho em Saúdc (Pils) e. mais recentemente e de forma mais destacada. o Pro. grama de Incentivos às Mudanças Curriculares nas Escolas Médicas (Promed).

Estc sumb́rio de realizaçoes conjuntas representa apenas parte da história que asroxima as duas instituiçoes. Esperemos que o eco dessa homenagen prestada pela Organizaç̧o Pan-Americana da Saúde à sua parccira brasileira no campo da Educaçăo Médica se faça ouvir nos congressos vindouros. com a apresentaça de trabalhos de pesquisa histórica que resgatem as origens, os determinantes $\mathrm{c}$ as implicaçoes dos movimentos que têm marcado o passado da Educaçåo Médica no Brasil c que, certamentc, orientarăo scu futuro. 